\title{
A tudástársadalmak mélystruktúrája
}

A web-alapú alkalmazások utóbbi időben bekövetkezett robbanása nyomán megválaszolásra váró kérdések sora vetődik fel. Mi fog történni azokkal, akiknek nincs hozzáférése az új digitális hálózatokhoz és eszközökhöz? Vajon az új szolgáltatások képesek lesznek-e kielégíteni az emberek eltérő információ-igényeit? Vajon elegendően nagy számú ember jut-e azon képességek, kapacitások birtokába, melyek révén a digitális információs erőforrások használható tudássá alakíthatók? Amennyiben nem történik kellő befektetés az emberek eredményes bekapcsolódását biztosító társadalmi képességekbe, a digitális technológiákban rejlő lehetőségek sokak számára továbbra is elérhetetlenek maradnak.

\section{Szerzői információ:}

\section{Robin Mansell}

A Londoni Egyetem Közgazdaság- és Politikatudományi karán az Új média és az Internet tanszék vezetôje. Kutatóként elsôsorban az információs és kommunikációs technológiai újításokból eredő társadalmi, gazdasági és politikai problémák, illetve az új média és az Internet szabályozásának kérdései foglalkoztatják. Kutatásaiban együttműködő partnerei: az OECD (Gazdasági Együttmúködési és Fejlesztési Szervezet), az ENSZ, minisztériumok és cégek, valamint számos szervezet, mely az e-kereskedelmi és az e-kormányzati szolgáltatások globális hálózatának fejlesztésével foglalkozik.

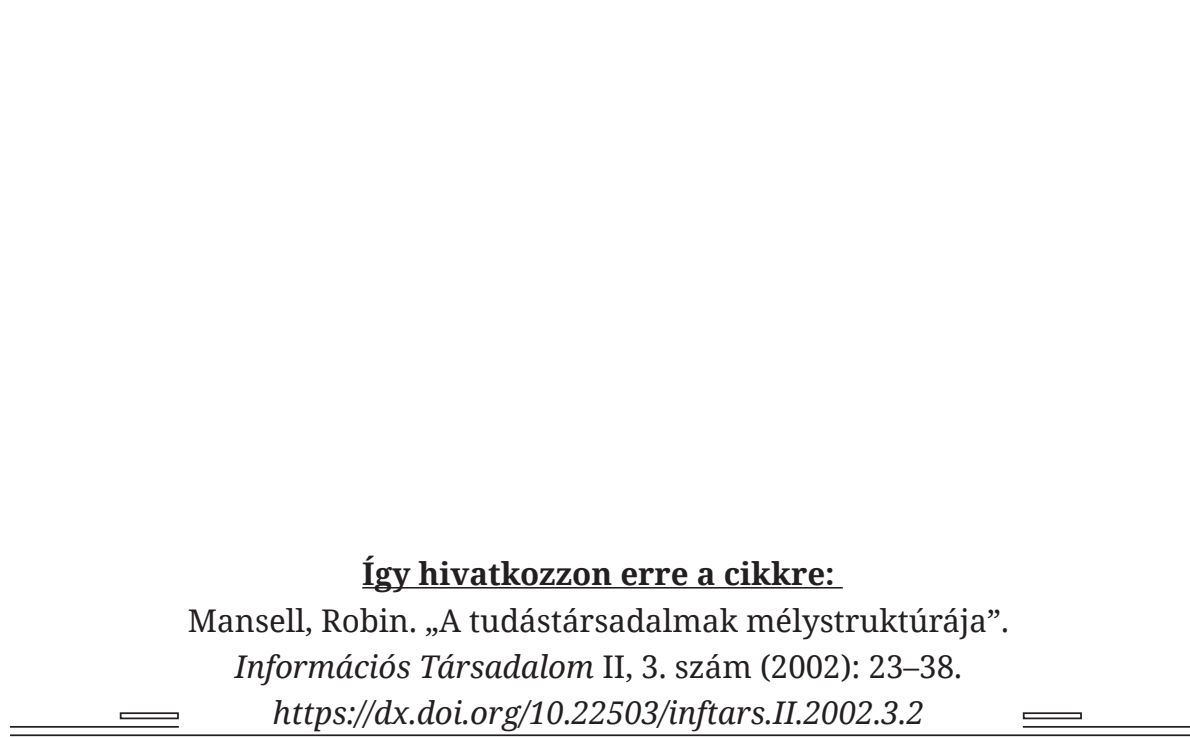

A folyóiratban közölt müvek

a Creative Commons Nevezd meg! - Ne add el! - Így add tovább! 4.0

Nemzetközi Licenc feltételeinek megfelelöen használhatók. 


\title{
Robin Mansell
}

\section{A tudástársadalmak mélystruktúrája}

\begin{abstract}
„A globális piacok, a globális technológia, a globális ötletek, és a globális szolidaritás mindenütt jobbá tehetik az emberek életét. A kihivást annak garantálása jelenti, hogy az elónyös lehetöségekböl mindenki igazságosan részesüljön, és hogy ez az egyre nagyobb fokú egymásrautaltság az emberek javát szolgálja, s ne pusztán a haszonra törjön." (UNDP Human Development Report 1999)
\end{abstract}

\section{Bevezetés}

A digitális technológiák elképesztô mennyiségú információ létrehozását, tárolását és feldolgozását teszik lehetôvé. Ebben a minőségükben az elektronikus kereskedelem, valamint az üzleti vállalkozások és állampolgárok számára kialakított elképesztően sokféle szolgáltatás háttértámogatására használják fel ôket. A kialakulóban levố és a digitális technológiák által számottevốen megtámogatott tudástársadalmakban kedvtelés vagy haszonszerzés céljából történő részvétel egyre inkább megkívánja az információs és kommunikációs hálózatokhoz és szolgáltatásokhoz való hozzáférést.

A társadalmi és gazdasági fejlődés és növekedés szempontjából kulcsfontosságú problémákat az állami, a magán- és a nem kormányzati szféra tagjai, valamint a civil szervezetek sok esetben együttes közremúködés nyomán igyekeznek megoldani. Annak ellenére, hogy az internet fejlődése már jó ideje folyamatban van, a világhálónak az elektronikus levelezés, valamint a web-alapú alkalmazások céljaira történő felhasználásában - az utóbbi idôben bekövetkezett robbanás nyomán - újabb megválaszolásra váró kérdések vetôdnek fel. Mi fog történni azokkal a polgárokkal, akiknek nincs hozzáférése az új digitális hálózatokhoz és eszközökhöz? Vajon az új információs és kommunikációs szolgáltatások képesek-e kielégíteni az emberek eltérố információs igényeit? Vajon elegendően nagy számú ember jut-e azon képességek, kapacitások birtokába, melyek révén a digitális információs erőforrások használható tudássá alakíthatók? Azok a polgárok, akiknek nem áll módjában, hogy hozzáféréshez jussanak és használják az elektronikus hálózati infrastruktúrákat és szolgáltatásokat, nem részesülhetnek azokból az előnyös lehetôségekből, melyeket megragadva a szakképzés és oktatás új formái révén továbbfejleszthetnék képességeiket; nem tudják majd élvezni a foglalkoztatottság és jövedelemszerzés új formáit, módozatait. S amennyiben ezeket a szolgáltatásokat a jövôben főként elektronikus úton biztosítják majd, könnyen előfordulhat, hogy kirekesztôdnek abból az állampolgári körből, melynek módjában állhat kihasználni az állami szolgáltatások előnyeit. Azoknak, akik nem férhetnek hozzá az új elektronikus szolgáltatásokhoz és használhatják kreatívan ezeket a szolgáltatásokat, nem lesz lehetôsége arra, hogy hálózati szoftvereket és információs szolgáltatásokat hozzanak létre, vagy, hogy globális szinten dobják piacra helyileg 
megtermelt árucikkeiket. Nemkülönben egyre nagyobb nehézséget jelent majd számukra, hogy a napjaink elektronikus hálózatain terjedő, nem kereskedelmi jellegú információs tartalmak pazar bôségét tovább bôvítsék, vagy éppen élvezzék.

Ha volna meggyőző bizonyíték arra, hogy a hálózatok és a digitális technológiákat alkalmazó elektronikus szolgáltatások piac-vezérelte fejlődése kész meghajolni a befoglaló jellegú tudástársadalmakba való zökkenômentes és gyors átmenet előtt, cáfolhatatlan érv állna rendelkezésünkre, hogy szembehelyezkedjünk azzal az állásponttal, mely szerint egy egyre szélesedo „digitális szakadék” keletkezett. Az új digitális szolgáltatások és alkalmazások mindazonáltal még mindig egy viszonylag korai fejlődési fázisnál tartanak. Az iménti állásfoglalás alátámasztására mindazonáltal csekély bizonyíték áll rendelkezésünkre (Mansell \& Wehn, 1998; Mansell \& Steinmueller, 2000), amit fő́ként azon cégek állításaira alapozunk, melyek a digitális technológiák és szolgáltatások kereskedelmi célú kínálatának piacán igyekeznek pozíciójukat erôsíteni (Leebaert, 1998). A digitális szakadék valószínúsíthetô fennmaradására utaló jelek - még ha csak átmeneti idôre szólnak is - azt jelzik, hogy a politikai irányelvek alakítóinak foglalkozniuk kell annak a társadalmi és gazdasági következményeivel, hogy akadnak olyanok, akik nem tudnak részt venni a kialakulóban levő tudástársadalmakban.

Vannak, akik azt bizonygatják, hogy a társadalmi és gazdasági rend kohézióképességét a növekvő digitális szakadék feltehető következményeképpen fenyegető veszélyek azt jelzik, hogy a legnagyobb prioritás az „új gazdaság” új technológiáiba, hálózati infrastruktúráiba és szolgáltatásaiba történố beruházások ösztönzése kell, hogy legyen (KPMG, 2000; Kereskedelmi Minisztérium, 2000). Munkánkban elsősorban amellett kívánunk érvelni, hogy ez a nézet megfontolatlan. Pusztán az információs és kommunikációs technológiákba és a szolgáltatási piacokba történő beruházás nem elegendô ahhoz, hogy minimálisra csökkentse azt a társadalmunkat érő veszteséget, mely a folyamatosan fennálló digitális szakadék meglétéből ered. Amennyiben nem történik kellố befektetés azon társadalmi képességekbe, amelyekre azért van szüksége az embereknek, hogy eredményesen kapcsolódhassanak be a kialakulóban levő információ-érzékeny társadalmakba, a digitális technológiákban benne rejlő előnyös lehetôségek sokak számára továbbra is elérhetetlenek maradnak. Ez a képesség-együttes magában foglalja az általános múveltséget és a szakmai kompetenciákat, a modern szervezetek finanszírozásához és múködtetéséhez szükséges képességeket befolyásolni tudó intézményeket, valamint a kockázatokat, ösztönzóerôket, és a személyi érdemek társadalmi megbecsülését is magában foglaló, jutalmazását befolyásolni tudó, politikai és társadalmi tényezőket (Ohkawa \& Rosovsky, 1972). A tudástársadalmak mélystruktúrája nem pusztán technológiai jellegú, hanem finoman be van ágyazva azokba az emberekbe, akik rendelkeznek a digitális információs és kommunikációs szolgáltatások szükségleteik és kívánalmaik szerinti használatához szükséges társadalmi képességekkel.

A társadalmi képesség-együttes fontosságának felismerése a politikai irányelvek meghatározása szempontjából az emberekbe való befektetést jelenti. Azt jelenti, meg kell találni az elektronikus vagy „virtuális” környezetekben végezhetố társadalmi és gazdasági tevékenységek folytatásához szükséges, szakértelmi bázisba történô befektetésre alkalmas, vonzó és fenntartható környezet kialakításának új módjait. Az új szolgáltatások értékbecsléséhez és kiválasztásához, valamint kreatív alkalmazásához 
és használatához szükséges képesség-együttes különös fontossággal bír; mely képesség-együttes magában foglalja a számítógépes írástudást és a hálózati navigációs készséget, valamint azon összefüggés-rendszerek tudatos felismerését, amelyekben a digitális információk létrejönnek. Meglehet, hogy az újságok fócímei multimédiatudásalapú társadalmak vízióit vetítik elénk, a webes músorszolgáltatás hívei pedig az interneten keresztül közvetített folyamatos audio- és videotartalmak dicséretét zengik, vannak azonban olyan komplementer fejlődési mozzanatok is, melyeket a tudástársadalmak kibontakozásával párhuzamosan szintén figyelembe kell venni. Az információ megszerzésének és releváns tudássá alakításának költségei a digitális információknak az információs robbanás alapját képező rendkívül alacsony sokszorosítási költsége ellenére is magasak, és nem mutatnak szükségszerúen csökkenô tendenciát. Sốt az is megeshet, hogy a szóban forgó költségek növekedni fognak, ahogy társadalmi és gazdasági rendszereinkben az információbőség egyre nagyobb fokú bizonytalansággal és bonyolultsággal társul. Ennek nyomán valószínúleg továbbra is megmarad a digitális szakadék.

Az információ megszerzésének és tudássá alakításának költségei azok számára képeznek akadályt, akik nekik tetsző tudástársadalmakat szeretnének létrehozni. Az ilyen társadalmak valószínúleg olyan tudáskörnyezetből fognak kifejlődni, amelyek új foglalkoztatási lehetôségek megteremtődéséhez, valamint a virtuális terekben zajló tevékenységek új értékalapjainak kollektív megvitatásához járulnak hozzá. Ezek szignifikáns költségek, mivel ezek révén kell gondoskodni arról, hogy az emberek többsége ösztönözve legyen arra, hogy megszerezze azon kognitív képességeket, melyek birtokában sikeresen kapcsolódhat be az új gazdaságba. Az új gazdaság központi elemévé fejlődő digitális technológiákhoz és szolgáltatásokhoz való megfizethető hozzáférés híján valós a kirekesztôdés veszélye, és ez nemcsak a globális kereskedelemre igaz, hanem azokra a virtuális közösségekre is, amelyek helyileg, illetve országaik és régióik között teremtenek kapcsolatot az emberek között. Az emberek saját társadalmukból való kizárása ellentmond a társadalmi igazságosság fennálló alapelveinek. Mindez kellő kényszerítő erôt hordoz magában a cselekvő fellépésre, illetôleg a politikai irányelvek meghatározóinak arra nézve, hogy a technológiai infrastruktúra fejlesztésére irányuló törekvések mellett a kialakulóban levố tudástársadalmak kohéziójának erősítéséhez, valamint a kirekesztődés veszélyeinek elhárításához szükséges társadalmi képesség-együttesre is kellő figyelmet fordítsanak.

\section{A tudástársadalmak mélystruktúráiának megértése}

Még abban az esetben is fontos figyelmet fordítani a kialakulóban levő tudástársadalmak mélystruktúráját formáló számos egyéb kulcsmozzanatra, ha az internethez és a hasonló technológiai infrastruktúrákhoz és szolgáltatásokhoz való általános és megfizethető hozzáférés hagyományos céljait sikerül is megvalósítani a politikai és piac-vezérelte fejlesztések révén. Ezek mindegyike annak az összetett hibridizációs folyamatnak a következményeivel függ össze, amely az újfajta tudástársadalmakban megy végbe. A hibridizáció olyan folyamat, amely a szülő́k elônyös tulajdonságait olvasztja egybe. A biológia világában a kedvezôtlen tulajdonsággal bíró utódokról legokosabb lemondani. Néha reprodukcióra képtelen utód jön létre, mint amilyen 
például az öszvér. A társadalom világában ahova csak tekintünk, a szereplők hibrideket hoznak létre az új gazdaság számára, melyek elốnyös és kedvezốtlen tulajdonságokkal egyaránt rendelkeznek. A gyorsabb ütemú hibridizáció a biológia világában megfelelő alapot ad a legrátermettebb teremtmények kiválasztására. A hibridizáció koncepciójának (a társadalmi kontextusra vonatkozólag Rogers dolgozta ki még 1962-ben) kiterjesztése hasznos lehet a társadalom világában zajló analóg folyamatok megértéséhez. Például, hogy a kedvezô technológiai, társadalmi és gazdasági minôségek milyen keveréke nyomán jönnek létre sikeres új információs és kommunikációs szolgáltatások az állampolgárok számára? Ha a gyorsabb ütemben zajló hibridizáció megfelelő alapot képez a „legrátermettebb” kiválasztására, és a hibridizáció folyamata Európában valamelyest lassabban zajlik, mint az Egyesült Államokban, akkor vajon ez mit von maga után a politikai irányelvek szempontjából?

A hibridizáció első lényeges területe az adatok hálózatosításával van összefüggésben. Az adatcsomagok forgalmát irányító eszközök és kapcsolóberendezések gyártóinak a célja az adattovábbítás és az információ terjesztésére megfelelô hibrid hang- és adattechnológiák létrehozása. Azért hoznak létre hibrid technológiákat, hogy kezelni tudják azt az elképesztô adatmennyiséget, amely a számítógépes rendszerek között továbbítódik, cserélődik. S ami még lényegesebb, adathálózatokat hibridizálnak, hogy kézben tudják tartani a hang-alapú szolgáltatásokat, valamint a gyorsabb és megbízhatóbb adatkommunikációs szolgáltatásokat. Egyes új technológiák az intraneteket és a helyi hálózatokhoz való távoli hozzáférést garantált sávszélességgel, valamint a távbeszélő és multimédia alkalmazásokhoz kialakított sajátosságokkal ötvözik. A globális szinten múködô távközlési társaságok, mint például a WorldCom megvalósítják ezeket a hibrid technológiákat. A szóban forgó szolgáltatások iránti igény Európában nem olyan meghatározó, mint az Egyesült Államokban (OECD, 2000). Az európai hírközlési hálózatok üzemeltetối hátrányba kerülhetnek, amennyiben nem támogatják ezeket az új szolgáltatásokat, de azért képesnek kell lenniük arra, hogy felügyeljék és kézben tartsák ezeket az új hálózatokat és foglalkozzanak a helyi hálózatok egyéni sajátosságaival, ha megfelelő infrastruktúrát kívánnak biztosítani az új gazdaság szolgáltatásainak európai felhasználói számára. Az új hálózatoknak a magánszféra védelmére, megfelelő karbantartásra, valamint támogatási és számlázási struktúrákra van szüksége. Az új hibrid infrastruktúra üzemeltetése terén ráadásul jóval lassabban gyưlnek a tapasztalatok Európában, ami fơként a kevésbé kiélezett piaci versenynek tudható be. Ennek a következménye, hogy Európában a hálózati infrastruktúra egy lényeges aspektusa egyszerre kevésbé hozzáférhetô és költségesebb az azt felhasználó polgárok számára, mint az Egyesült Államokban.

A hibridizációs folyamatnak az új gazdaság mögött meghúzódó második jellemző sajátossága az innovatív hibrid üzleti modellekkel kísérletezô cégek szervezésbeli törekvéseiből tûnik ki. Az Amazon.com példája egyre ismertebb. Ez a vállalat számos követôjével egyetemben nagy kedvezménnyel értékesíti termékeit arra kényszerítve a disztribútorokat és kiskereskedőket, hogy a legminimálisabb árréssel dolgozzanak. A független könyváruházakra és más kiskereskedôkre az Amazon.com és az óriáskönyvkereskedô láncok kettôs nyomása nehezedik. Érdemes felidézni John Stuart Mill 1868-ban tett észrevételét, mely szerint „ha a társadalom megérett az újjáépítésre, nincs értelme annak, hogy a hagyományosan bevett elgondolás (old plan) alapján fogjunk hozzá az újjáépítéshez”. Az online szolgáltatási iparban a „ha- 
gyományosan bevett elgondolás" védi a szellemi tulajdon birtokosainak jogait; ez az elgondolás nagyon is életben van azon törekvéseknél, amelyek a digitális információs termékek esetében hathatósabb szerzői jogi védelmet hivatottak érvényre juttani. Az új dotkom cégek közül azonban soknak már új elgondolása van, ami olyan hibrid üzleti modellek bevezetésében áll, amelyek számításba veszik azt a tényt, hogy a globális hálózatok segítségével az emberek könnyűszerrel másolhatják az online információkat. Az új üzleti modellek felismerik, hogy a releváns információkra egyre nehezebb rálelni. Az információk idôszerûsége, minôsége és pontossága az üzleti vállalkozások, fogyasztók és állampolgárok számára gyakran sokkal fontosabb, mint maga az információ. Közbensô szolgáltatásokra van szükség, hogy segítsenek az embereknek meghatározni információs szükségleteiket, illetve hogy a szolgáltatások kreatív összerendezése révén segítsenek számukra abban, hogy kielégítsék az igényeket. A digitális tartalom az újfajta tudástársadalmakban gyakran egyszerűen a segítségnyújtó, valamint az információkat összesítô, szúrô, és integráló szolgáltatások propagálását, hirdetését jelenti (Dyson, 1997). Az új hibrid cégek közül sokan arra koncentrálnak, hogy „szabad” hozzáférést biztosítsanak a digitális tartalmakhoz, valamint, hogy értékesítsék a kapcsolódó szolgáltatásokat. Ezek után még mindig ott a kérdés, vajon ezek közül az új cégek közül hányan maradnak életben, hogy a jelenleg talpon levôk képesek-e elegendő változatosságot produkálni ahhoz, hogy felvegyék a versenyt az új hibridizálókkal, és hogy vajon a nem helyi cégek rájönnek-e arra, ki értékeli az információkat, mikor van szükség az adott információkra, és milyen készségekkel kell az embereknek rendelkeznie ahhoz, hogy előállítani és felhasználni is egyaránt képesek legyenek az információkat. A bizonytalanságot és a kísérletezést javarészt az új bevételi források utáni hajsza, illetôleg a jövốbeni haszon reménye szüli (Mansell \& Steinmueller, 2000). Az új szervezeti formákkal történő kísérletezgetés a nem kereskedelmi világban is megfigyelhetô a kulturális információcsere területén (Neice, 2000). Ez egy olyan terület, amely ösztönözhető olyan állami politikai kezdeményezésekkel, amelyek fejlesztik a polgárok (teljesítô)képességeit, hogy az új virtuális környezeten belül új társadalmi és kulturális közösségeket kovácsoljanak.

Az újfajta tudástársadalmak irányába történő elmozdulás mögött rejlô harmadik lényeges aspektus a tanulás terén megjelenő innovációkat és az új kognitív képességek összevonását foglalja magában. A tudástársadalomban való részvételhez szükséges szakértelmi háttér fejlesztésének problémája nem oldható meg egyszerűen azáltal, hogy növeljük a számítástechnikai és egyéb speciális szakképzésben részesülő hallgatók számát. Nem oldható meg pusztán úgy, hogy nagyobb hozzáférést biztosítunk a hardver-eszközökhöz és az azokat összekapcsoló hálózati rendszerekhez. Egyre inkább olyan polgárokra és dolgozókra van szükség, akik hibrid szakmai, szervezeti és információmenedzsment ismeret- és képességegyüttessel rendelkeznek. Jelenleg nagyon keveset tudunk arról, miként nevelhetốk ki olyan emberek, akik rendelkeznek azokkal a hibrid képességekkel, amelyek segítségével stimulálható az online szolgáltatások és a különféle típusú elektronikus információk iránti szükséglet. Ráadásul az informatikai szakemberek túlnyomó többségét sem képezték ki arra, hogy kreatívan kezeljék az információkat, vagy hogy gyakorlatban hasznosítható tudást kovácsoljanak az információkból (Roche \& Blaine, 2000). A cégvezetôk, fogyasztók és állampolgárok csak csekély információtechnológiai szakértelemmel ren- 
delkeznek. Oktatási rendszereink egyszerûen nem termelnek ki elegendő embert, akiknek megvan az új gazdaságba való produktív bekapcsolódáshoz szükséges kompetencia-profilja. Egyre nagyobb a kereslet az olyan képességek iránt, melyek alkalmassá tesznek valakit a releváns információk kiválasztására, az irreleváns információk figyelmen kívül hagyására, az információs mintázatok felismerésére, az információ értelmezésére és dekódolására, valamint új készségek elsajátítására és a régiek elfeledésére. A digitális információkhoz való hozzáférés és az új tudáshálózatokban a többi emberrel való összekapcsolódás képessége befolyással van az egyének és cégek hierarchián belül elfoglalt pozíciójára (OECD, 1996). A jól jövedelmezô állások esetében ezek a készségek-képességek nagyon gyorsan a versenyképesség és a kedvező munkahelyi kilátások központi elemévé fejlődnek. Nincs túl sok kitapintható jele annak az motivációnak, amely abba az irányba hatna, hogy újra kellene gondolni, mit és miként tanulnak az emberek a virtuális környezetekben. Azok a cégek és országok, amelyek a hibridizációs folyamat fentebb vázolt aspektusának megértik a lényegét, valószínúleg nagyobb sikerrel járnak a befoglaló jellegú tudástársadalmak kiépítésében, mint mások. A tudástársadalmak mélystruktúrájának iménti hibridizációs aspektusa nagyon lényeges megfontolandó tényező a politikai irányelvek meghatározói számára.

A kialakulóban levố európai és egyesült államokbeli tudástársadalmakon belül zajló folyamatok és az ott megfigyelhetô új struktúrák elemzéséből nyerhetô egyik tanulság az, hogy a folyamat üteme az Egyesült Államokban az innovatív folyamatok sokkal változatosabb formáit hozza létre (Mansell \& Steinmueller, 2000). Ahogy arra már fentebb rámutattunk, amennyire a biológiai analógia áll a társadalom világára is, a hibridizációs folyamat által az Egyesült Államokban eredményezett gyorsabb ütem és nagyobb változatosság azt vonja maga után, hogy az amerikai cégeknek nagyobb esélyük van arra, hogy az általuk kialakított információs és kommunikációs szolgáltatások vonzóerốt gyakorolnak az európai felhasználókra. Az Egyesült Államokban a technológiák, szolgáltatások és a népesség birtokában levố készségek tárháza nagyobb változatosságot mutat, mint Európában. A csak a lényegre koncentráló alapvető gazdasági elemzés ugyanakkor nem jut el az esetlegesen kijövő eltérô eredményekig, ahol az Európán belül, európai cégek által kialakított új szolgáltatások kedvezó fogadtatásra lelnek az európai felhasználók körében. A terület piaci fejlődésének hagyományos gazdasági elemzése elsiklik az európai környezet kontextuális sajátosságai felett, lehetetlenné téve az európai országok azon társadalmi és kulturális különbözőségének figyelembe vételét, amely a hagyományos elemzés eredményeit a „feje tetejére állítja”. Az ilyen elemzés azt sem ismeri fel, hogy az európai cégek által kínált termékek és szolgáltatások választásának esélye állami politikai kezdeményezések révén tovább növelhetố.

Az előbb említett észrevételeknek számos politikai következménye van. Európában a legfontosabb politikai prioritás az európaiak rendelkezésére álló tanulási lehetôségek eredményes kibôvítése, illetve alapvetố változás bekövetkezése a tanult anyag terén. A második prioritás, hogy az európai információs és kommunikációs technológiai ipar által alkalmazott üzleti modellek terén nagyobb rugalmasságot hagyjunk, valamint hogy az új digitális információs szolgáltatások kialakításakor a kereskedelmi és a nem kereskedelmi kísérletezést egyaránt ösztönözzük. A harmadik prioritás, hogy ösztönözzük a hibrid adatokkal és a hangkommunikációs hálózatokkal való kísér- 
letezést Európában. A fenti prioritások sorrendje rendkívül lényeges: tanulási lehetőségekbe történô beruházások, innovatív és kísérleti információs szolgáltatási kínálat előmozdítása, és beruházás új hálózati kapacitásba. A politika irányítói gyakran fordított sorrendbe teszik ezeket a prioritásokat, ami az egyik legfóbb fenyegetést jelenti a különféle tudástársadalmak európai kifejlődésére nézve. A társadalmi és kulturális politikai irányelvek éppoly lényegesek az európai tudástársadalmi színtéren, mint az új gazdasághoz társuló gazdaság- és technológiapolitikák.

\section{A tanulás szükségessége a sajátságos tudástársadalmakban}

A bőséges információ nem azonos értelmű a hasznosítható tudással. Robert Lane amerikai szociológus még 1966-ban használta a „tudásképes társadalom” (knowledgeable society) szakkifejezést. Lane felvetette, hogy a társadalmak megkülönböztetése aszerint történik majd, hogy miként gyưjtik, rendszerezik és értelmezik az ismereteket. Az 1950-es években alkotó John Bernalt fóként a tudományos ismeretek rendszerezésbeli innovációi érdekelték. Egy évtizeddel később Michael Polanyi (1966) foglalkozott azzal, vajon a „hallgatólagos” (tacit) (nem kodifikálható) tudás a technológiai innováció elốrehaladtával kivonja-e magát az információcsere alól. Bár az említett elemzốket az információ előállításának és fogyasztásának mikéntje érdekelte, a tudásképesség (knowledgeability) kérdéskörére irányított figyelem elvezette óket oda, hogy eltöprengjenek azon is, vajon koruk technológiai eredményei nem kerülnek-e ellentmondásba az állampolgárok lehető legszélesebb mértékú társadalmi részvételével. Manapság a digitális információ és kommunikáció technikai infrastruktúrájának felépítését is hasonlóképp kell megközelítenünk, ha meg akarjuk érteni, hogy a kialakulóban levő tudástársadalmaink mélystruktúrája miként függ össze az állampolgárok részvételi lehetőségeivel.

Az új technikai infrastruktúra felépítésének egyik jellemzôje, hogy a piaci szereplőknek módjában áll olyan információs szolgáltatási csomagokat kialakítani, melyek garantálhatják beruházásaik sikerét (Mansell, 1999). Mindez lehetőséget teremt a cégek számára, hogy az információs szolgáltatási piacok monopolizálásának új módozatait vezessék be az által, hogy a disztribúciós csatorna mentén olyan 'upstream' és 'downstream' kapcsolatrendszereket alakítanak ki, amelyek révén kézben tarthatják a beruházási döntéseket, valamint irányításuk alá vonhatják a tudástársadalmak egyes információs átjárási pontjait (information gateways). A tudásképesség kérdéskörének perspektívájából nézve a kérdés az, vajon a polgárokhoz és fogyasztókhoz vezetô átjárási pontokat felügyeletük alatt tartó hálózati operátoroknak és szolgáltatóknak módjában kellene-e hogy álljon, hogy kirostálhassanak bizonyos információkat: akár azért, mert nem képeznek folyamatos bevételi lehetôséget, akár azért, mert az vetekszik saját információikkal? Amennyiben a kirostált információ létfontosságú a legáltalánosabb körben megvalósuló tanulás, vagy a hatékony üzleti tevékenységek és társadalmi törekvések szempontjából, kellô érv áll a politikai irányelv-alkotás mellett, hogy gondoskodjon arról, hogy az állampolgárok alapvető információs szükségletei ne maradjanak kielégítetlenek. 
Az információtermelés és a kommunikáció szolgálatába állított valamennyi új technológiai fejlesztéshez történelmileg társul a maga politikai irányelvekhez kötődő problémaköre. Minden egyes új fejlesztés keresztülmegy egy olyan perióduson, melyben a szolgáltatás nyilvános hozzáférhetôsége korlátokba ütközik. Kezdetben a postai szolgáltatás is az írni-olvasni tudókra, valamint a társadalom tehetôsebb rétegeire korlátozódott. Eleinte a távbeszélố szolgáltatás kapcsán is úgy vélték, csak a társadalmi és üzleti közösségek kisebb szegmensei értékelik majd a lehetôség hasznosságát. (Flichy, 1995; Marvin, 1988). Ma az internet-penetráció és az állampolgárok információhoz való hozzáférési jogával összefüggó megfontolások új problémákat vetnek fel a politikai irányelvek meghatározása terén, ami a tudástársadalmakban való részvételhez szükséges ismeretszerzés, illetve készségek elsajátításának vonatkozásában bír különös jelentőséggel.

Az újfajta tudástársadalmakban való részvétel sokkal többet foglal magában, mint puszta „hozzáférést” a hálózatokhoz és az információkhoz. Az internetes környezet egyidejúleg teremti meg a lehetőséget az egyének számára, hogy információgyưjtők és információszolgáltatók legyenek. Ez egy nagyon különleges és egyedi sajátsága az új digitális infrastruktúrának. Elvben például bárki létrehozhat honlapot a weben. Az internethasználat ugyanakkor a telefonhasználattal szemben a felhasználó képességeinek és készségeinek fejlettségétől is függ. Ezek a kompetenciakörök, jártasságok az interaktív kommunikációt, az információterjesztést, és az információgyújtést is magukban foglalják. Az információk szelektáló keresését végzố keresőrendszereknek nincs ekvivalens párja a telefonhálózatokon belül. Az interneten keresztül elérhetô információs erôforrások skálája minden egyéb kommunikációs médiumét felülmúlja. Az Internet nem felhasználóbarát szoftverekre épülő hálózatok laza együttmúködéséból tömegfelhasználásra alkalmas globális kommunikációs hálózattá fejlődött. Hogyan történhet hatékony tanulás úgy, hogy az internetes szolgáltatások használata a lehető legkiterjedtebb állampolgári kör számára biztosított?

$\mathrm{Az}$ internetes készségek és jártasságok kialakítása szempontjából releváns általános oktatási és képzési szolgáltatások biztosítása legalább olyan fontos, mint a technológiai infrastruktúrához való általános hozzáférés feltételeinek megteremtése. Ahogy az Európai Bizottság egyik beszámolója fogalmaz: „ha elfogadjuk az érvelést, mely szerint a technológiai képesség-együttes folyamatos fejlesztése összetett átalakulási folyamatot sejtet, nyilvánvaló, hogy a politikai irányelveket nem lehet, és nem szabad a technológiai változás gazdasági integrációjának biztosítására leszúkíteni, hanem az említett változások szélesebb társadalmi integrációjának valamennyi egyéb aspektusára is ki kell terjeszteni." (High Level Group of Experts, 1997). Ez azt jelenti, hogy az új elektronikus környezetekbôl való tényleges vagy potenciális kirekesztôdés problematikájának kezelésére hivatott társadalmi és kulturális irányelveket éppoly gondosan kell kialakítani, mint az új környezetekben történő üzleti tevékenységek ösztönzésének szabályozó irányelveit. Ha például az internetszolgáltatók szabványos kapcsolaton keresztül átalánydíjért kínálnak korlátlan internet-hozzáférést, az nem fogja teljesen megoldani a társadalmi kirekesztődés problémáját. Az állampolgároknak számítógépes írástudással (computer literacy) is rendelkezniük kell, és jártasnak kell lenniük a számítógépes kezelőfelületek használatában is. Az állampolgárok az információk kikeresése és egységbe rendezése terén nagyobb fokú segítségnyújtást igényelnek, mint a távbeszélő szolgáltatások 
esetében. Az újfajta tudástársadalmakban való részvételhez szükséges készségek és társadalmi képességek megszerzése kulcsfontossággal bír a polgárok kellő döntési és cselekvési szabadsággal való „felvértezése” (empowerment) érdekében. A polgárokra a tanulási folyamatot elôsegítô, az innovatív technológiák révén rendelkezésre álló hallgatólagos és kodifikált tudás sajátságosan egyedülálló kombinációja ugyancsak erốteljes befolyást gyakorol.

Számos internet-hozzáférési modell van kialakulóban, melyek mindegyikének jelentősége van abból a szempontból, hogy az új készségek és képességek megszerzése terén milyen lehetőségek állnak az állampolgárok rendelkezésére, valamint abból a szempontból, hogy ennek érdekében milyen költségvonzatok érinthetik óket. (Geuna \& Steinmueller, 1997; Mansell \& Steinmueller, 2000). Az egyik ilyen modell a szervezeti hozzáférési modell. A nagy szervezetek által rendszerint használt internetkapcsolat egy bérelt vonal, valamint a szervezeten belüli személyi számítógépek közti összeköttetést megteremtô helyi hálózat (LAN) révén jön létre. A technikai rendszer felügyeletét, a szolgáltatások biztosítását, valamint a képzéshez szükséges segítségnyújtást egy szervezeten belüli speciális team végzi; esetleg a szervezet ezen feladatköreinek egy részét külsô szerződéses vállalkozók megbízásával is „kiszervezheti" (outsource) a vállalatból. Az internet-hozzáférés költségei rendszerint a szolgáltatót megilletố elôfizetôi díjat, a hálózati kapcsolat bérleti dijját, a személyi számítógépek és a helyi hálózat költségeinek egy részét, illetve a menedzsment és képzési költségek bizonyos hányadát foglalják magukban. Ebben a modellben a végfelhasználót, azaz az alkalmazottat e költségek egyike sem terheli közvetlenül. Az intranetek (a nyilvános interneten használt eszközökhöz hasonló megoldásokat alkalmazó belső magánhálózatok) számának gyarapodása roppant gyors. Mindez azt eredményezi, hogy a cégek alkalmazottainak adott a lehetôsége arra, hogy megismerkedjenek az internethasználat eszközeivel, módszereivel. Az internethasználattal összefüggő készségek fejlesztéséhez ily módon a nagyobb szervezetek lényeges mértékben járulnak hozzá. Noha az általános internethasználati készségkör kialakításában történő szerepvállalás roppant értékesnek mondható, mégis felveti az említett készségek elsajátítása terén egyre inkább megmutatkozó egyenlőtlenség problémáját azok szempontjából, akik nem részesülhetnek az ilyen típusú szervezeti hozzáférés előnyeiből. A fenti hozzáférési modell meghonosítása érdekében tett céges szerepevállalás azt az állami politika által már hosszú ideje támogatott eredeti internet-elérési szervezeti modellt egészíti ki, amely a felsôoktatási intézményekben alakult ki.

A következő modell a polgárokat az internetszolgáltatóval összekapcsoló otthoni, vagy virtuális irodai kapcsolt vonalas internet-hozzáférési modell. E modell hozzáférési költségeibe a szolgáltatót megilletô előfizetési díj, a hálózati kapcsolat használati költsége (Európában a legtöbb esetben), a személyi számítógép hardver-költségeinek egy bizonyos hányada, valamint a szükséges készségek megszerzésének és a segítségnyújtásnak a költsége tartozik. Az említett költségek rendkívül lényeges részét képezi az a személyi befektetés, melyet az állampolgárnak kell felvállalnia annak érdekében, hogy megszerezze a szolgáltatások használatához szükséges ismereteket, készségeket. Ezek a költségek életkor és iskolázottság szerint eltérhetnek. Egy olyan iskolarendszer, amely megismerteti a tanulókat az új technológiákkal, csökkentené a polgárokat terhelő hozzáférési költségeket. A szolgáltatók és hardver-ellátók segít- 
ségnyújtó szolgáltatásainak kiszélesítése olyan piaci lehetôség, melyet az állami politikának ildomos volna oly módon pártfogolnia és előmozdítania, hogy az egy tudásra jóval fogékonyabb társadalmi és kulturális környezet létrejöttét eredményezze.

Szintén említést érdemel a közösségi internet-hozzáférési modell. Az internetszolgáltatások közösségi elérésének költségei hasonlóak az otthoni hozzáférési költségvonzatokhoz, a költségösszetevốk súlyozottsága azonban eltérô. A legnagyobb állami iskoláknak és könyvtáraknak a rendelkezésére állhatnak a bérelt vonalak használatára fordítható erőforrások, míg az átlagos méretű iskolák, könyvtárak és múzeumok rendszerint kapcsolt vonalas állami távközlési hálózatok útján jutnak hozzáféréshez, aminek sok esetben jelentôs hálózathasználati költségvonzata van. Rendszerint ugyanezen feltételek vonatkoznak azokra a kisvállalkozókra, akik internetkávézókat és más hasonló nyilvános elérési lehetőségeket alakítanak ki. Ugyancsak jelentôs a költségvonzata a felhasználók képzését megoldó, és számukra segítséget nyújtó szakképzett dolgozók alkalmazásának. (Betcherman \& McMullen, 1997; Richardson, 1999). A hálózatok és szolgáltatások elérhetôsége és megfizethetősége mellett a felsorolt modellek mindegyike esetében két másik összetevố is nagy fontossággal bír. Az egyik a felhasználót érintő eszközköltség, amely az egyre olcsóbb hardverek piaci megjelenésével, valamint a nyílt forrású szoftverek egyre jobb elérhetőségével párhuzamosan kedvezôen alakul. A másik a készségek elsajátításának költsége, ami továbbra is az újfajta tudástársadalmak irányába mutató befoglaló jellegû́ fejlôdés egyik legfốbb akadályát képezi. A cégekre háruló képzési költségeket az általános oktatás részeként megvalósuló képzés állami támogatása tudná csökkenteni. Ez a munkaadóknak is a javát szolgálná, mivel könnyebben rátalálhatnának az igényeiknek megfelelő képzettségi profillal rendelkezố emberekre. Amennyiben ezen a területen nem sikerül számottevố elôrelépést elérni, annak az lesz a következménye, hogy az elektronikus szolgáltatásokra egyre inkább ráutalt társadalmakban a hozzáférés megszerzésére a megfelelő készségek hiányában nem, vagy csak nagy nehézségek árán képes emberek egyre inkább a perifériára sodródnak és kirekesztődnek. A szükséges készségek megszerzésére alkalmas lehetőségek megragadásának politikai irányelvekben történố hangsúlyozása valószínúleg jelentôs eredményre vezetne, mivel a digitális információs szolgáltatások előállítóinak világos gazdasági érdeke egy megfelelő készségekkel rendelkező felhasználói tábor megléte, hiszen ez is előmozdítja a piaci fejlődést. Ebben a politikai irányelvek meghatározóinak is érdekeltnek kellene lenniük, hiszen őnekik kell gondoskodniuk arról, hogy a polgárok tudásképes módon vegyenek részt a civil társadalomban. Ez különösen így van azon lehetôségek esetében, amikor az idôsek, vagy csökkent munkaképességúek számára kialakított, illetve a felhasználók számára elérhetô szolgáltatások nyelvi sokszínűségét célzó információs és kommunikációs rendszerek megtervezésének elősegítéséról van szó (ASSENT, 1999 a és 1999 b).

\section{A "digitális kultúra" megteremtése}

Sherry Turkle (1988 és 1995) és a digitális kultúra más elemzői is megfigyelték, hogy a befolyásérzet és a helyzet uralásának, kézben tartásának számítógép- és internethozzáférés vonzataként megjelenő igézete különösen a fiatal férfiakra gyakorol 
nagy csáberôtt. A nốk felsôoktatásbeli számítástechnikai és mérnöki képzésben való részvételi aránya számos országban annak ellenére is visszaesett, hogy nem olyan országokban is szép számmal képviseltetik magukat a hálózaton, ahol az internethasználat foka viszonylag magasnak mondható. Ez pedig megkérdőjelezi a kialakulóban levő tudástársadalmak számára kialakítandó digitális kultúra autenticitását. Martin Buber (1970/1937) filozófus, teológus és pszichológus jegyezte meg, hogy „kezdetben van a kapcsolat [i viszony]”. Bubert különösen az érdekelte, hogy a „dialógus” által miként közvetítődik a tapasztalat és a kultúra (Buber, 1965/1948). A dialógusok résztvevői - beleértve az elektronikus levélhez hasonló szolgáltatások közvetítette dialógusok résztvevőit is - olyan kapcsolatokat létesítenek, amelyek motiválják a virtuális színterekben zajló munkát és játékot. Annak megértéséhez, hogy a nôk és néhány egyéb társadalmi csoport vajon miért vonja ki magát ilyen nagy mértékben az elektronikus dialógusok alól, figyelembe kell venni az ember/gép kapcsolódási felületek tervezési felépítését és azokat a kognitív eszközöket, amelyek az információs és kommunikációs rendszerek tervezőinek gyanítása alapján előbbiek használatára vonatkozólag léteznek. Az Internet felépítési-megszerkesztettségi módja befolyást gyakorol arra, hogy az emberek társadalmi vagy üzleti haszonszerzés céljából milyen kapcsolatok kialakítására szánják el magukat, hogy ezek a kapcsolatok kielégítőek vagy felzaklatóak-e, valamint arra, hogy miként illeszkednek be a mindennapi életbe. A tudástársadalmak kialakulóban levő digitális kultúrájában tetten érhetô instabil mozzanatokat helyrebillenteni igyekvő lényegi törekvéseknek a digitális kultúra hôsnôiire és hőseire egyaránt érintôlegesen hatniuk kell. Ennek érdekében egy minden korábbinál nagyobb mérvú kulturális részvételre-bevonódásra van szükség.

A digitális kultúra sokszínűségének elôsegítése nem csupán a nemek közti egyenlőtlenségek csökkentéséről, hanem a problémák felismeréséról, valamint az információtermelés és a kommunikáció megkönnyítése érdekében végbemenô fejlesztésekkel összevegyülten megjelenô társadalmi kirekesztettség enyhítése érdekében történô cselekvố fellépésről is szól. Az új digitális alkalmazások és eszközök egynémelyike éppen az információk összefüzésének és felhasználói kínálati módjának felépítményén keresztül járul hozzá a kirekesztődéshez (Mansell \& Steinmueller, 2000). Az információs termékek és szolgáltatások alternatív kombinációinak létrehozását motiváló tényezôk attól függôen térnek el egymástól, hogy a végcél üzleti haszonszerzés-e, vagy egyszerủen kulturális tapasztalatcsere.

Azt, hogy a közös cél érdekében szövetkezố emberek számára lehetôvé váljon, hogy az Internet és más új technológiák révén önkéntes érdekszövetségekbe tömörülhessenek, olyan politikai lépések tennék megvalósíthatóvá, melyek elômozdítják az elektronikus környezetekben kialakuló, nem kizárólagosan az üzleti haszonszerzés felé orientálódó virtuális közösségi kapcsolatrendszerek létrejöttét. A hacker-kultúra és a nyílt forrású szoftver-mozgalom tagjai például olyan robusztus társadalmi hálózatot alkotnak, amely tovább erôsíti azokat a képességeiket, melyek révén bekapcsolódhatnak a tudástársadalmak tevékenységeibe. Az ilyen közösségek tagjai üzeneteket tesznek közzé, megosztják egymással az információkat, valamint tudományos és egyéb szándékok által vezérelve felajánlják egymás számára a kölcsönös segítségnyújtás és együttmúködés lehetőségét (Raymond, 1999). Ezek a gyakorlati eljárásmódok, amelyek a kezdeti internetprotokollokat létrehívó egyete- 
meken belüli tudományos közösségekben eredeznek, késôbb az intenzív internethasználók egyéb csoportosulásainak (pl. újmédia-fejlesztôk) tárházába is bekerültek (Neice, 2000). A befoglaló jellegú tudástársadalmak kibontakoztatása érdekében rendkívül lényeges, hogy megértsük, miként jönnek létre és fejlôdnek tovább az ilyen közösségek. Szintén nagyon fontos, hogy nyugtázzuk azt is, miszerint az új Internetalapú társadalmi hálózatok eredményes múködésére nincs további kilátás a több tényezố által egyidejûleg vezérelt olyan folyamatok összehangolásának hiányában, melyek közül több a hagyományos társadalmi és üzleti eljárásmódoknak a virtuális szférába történő kiterjesztésével, átültetésével függ össze (Hawkins, Mansell \& Steinmueller, 1999).

Annak új módozatait pedig, ahogy az egyének a kulturális és tudományos tudásbázishoz hozzáillesztik a maguk tudásrészét, az elektronikus információk számára létrejövő kulturális tapasztalatcsere-modellek kialakításának tükrében kell értékelni. A tudományos kutatás és a kulturális információtermelés terén ki kell emelni azok érdemeit, akik információt hoznak létre, és azokét is, akik azt széles körben ismertté teszik. A digitális környezetben az információterjesztés céljából létrejövố piaci kapcsolatokra épülő árucsere modellekre fektetett kizárólagos hangsúly gátat vet az állampolgárok hathatós bekapcsolódási lehetőségeinek (Mansell \& Steinmueller, 2000). Amennyiben az embereket rá lehet bírni arra, hogy virtuális terek cselekvő részeivé váljanak, ki fogják fejleszteni magukban a dialógus új formáin való érintkezni tudás képességeit. Ez felbuzdíthat bennünket arra, hogy minél változatosabb módon értékeljük azokat, akik a digitális információ új formáit hozzák létre, felülemelkedve azokon, akik pusztán az árucikkekre és a profitra koncentrálnak (Mansell \& Steinmueller, 1998). Az interneten történő információtermelésre vagy „szerzőiségre” való buzdítás kulcsfontosságú eleme annak, hogy előmozdítsuk az olyan internetes tartalmak kialakítását, amelyek illeszkednek az európai kulturális, társadalmi és gazdasági kontextusba.

\section{Konklúzió}

Manuel Castells amellett érvel, hogy „elképesztôen nagy szakadék tátong technológiai túlfejlettségünk, valamint társadalmi alulfejlettségünk között. Gazdaságunk, társadalmunk és kultúránk olyan érdekekre, értékekre, intézményekre, és reprezentációs rendszerekre épül, amelyek nagyjából-egészében gúzsba kötik a kreativitást, elkobozzák az információs technológia számlájára írható javakat, illetve önpusztító konfrontáció felé térítik el energiánkat." (Castells, 1998). A kibontakozni igyekvő tudástársadalmaink hátterében álló politikai irányelvek és fennálló kormányzati modellek társadalmi alulfejlettségtôl szenvednek. Sokkalta nagyobb figyelmet volna ildomos szentelni annak, hogy a polgárokat miként lehet felvértezni (empower) azokkal a lehetôségekkel, képességekkel, amelyek a technológiai közvetítettség által egyre intenzívebben áthatott társadalomban való részvételük során megkönnyítik számukra döntéseik meghozatalát. Ráadásul minél nagyobb sikereket könyvel el a politika a technológiai infrastruktúrához való hozzáférés elősegítésében, annál nagyobb lesz az új társadalmi szakadékok és törésvonalak potenciális kialakulásának lehetôsége, ha a legtöbb embernek nemigen áll módjában döntéseket hozni arról, 
miként éljen hozzáférési lehetôségével. A népesség nagyrésze nem rendelkezik azokkal a technikai, illetve szociális készségekkel, amelyekkel a digitális környezet struktúráját formálhatnák, s még kevésbé azon készségekkel, amelyek révén produktív kapcsolatrendszereket alakíthatnának ki ebben a környezetben. Kevés figyelmet szentelünk annak, hogy ezeket az új készségeket, amelyek a kialakulóban levố tudásgazdaságokban a polgárok „felvértezésének” (empowerment) előfeltételei, miként tudná minél több európai polgár elsajátítani. Ezt a kérdést nem lehet megoldani úgy, hogy fớként az infrastruktúrához való hozzáférést és a tartalmi sokszínűséget szabályozó konvencionális eszközökre fektetjük a hangsúlyt. Úgy is kirekesztôdhetnek emberek a tudástársadalmakból, hogy egyszerúen alkalmatlannak bizonyulnak arra, hogy felismerjék az új digitális szolgáltatások értékét, hasznosságát, vagy hogy felismerjék, miként használhatnák ezeket a szolgáltatásokat társadalmilag és gazdaságilag produktív módon. A politikai irányelvek meghatározóan rendre az infrastruktúra szabályozására és a tartalomra helyezik a hangsúlyt a konvergenciával és az interneten elérhető szolgáltatások elterjesztésével szemben. A felelôsség terhe, illetve a kibontakozó tudástársadalmakba való bekapcsolódás költségterhe azonban egyre inkább a polgárokra nehezedik.

A feltalálástól a széleskörủ használatig terjedő úton valamennyi új technológia átalakuláson megy keresztül. Ez éppen annyira igaz a digitális információs és kommunikációs szolgáltatásokra, mint a fonográfra. Edison úgy hitte, a fonográfot főként a halálos ágyukon végakaratukat elrebegô jómódú úriemberek fogják majd használni! Használatba vételük során az új technológiai rendszerek gyakran drámai átalakuláson mennek keresztül, ez pedig alkalmasint „várjuk ki a végét” típusú fogadtatásra lel a politika alakítói részérôl. A mindinkább befoglaló jellegư és egyre tudásképesebb társadalmak előmozdítására képes technológiákat azonban a koordinációs elégtelenség klasszikus problémája jellemzi. Az új digitális termékek és szolgáltatások piaca nem kellően érett ahhoz, hogy egy olyan, viszonylag fixen kiformálódott szolgáltatáscsoport megjelenésérôl gondoskodjék, amely megfelelő alapot ad a polgárok piac vezérelte versenyen keresztüli tanulására, kísérletezgetésére. A szolgáltatásokat kínáló cégek az új piacok jövőbeni fejlődési irányait illető bizonytalanságukból fakadóan képtelenek zöldágra vergốdni szolgáltatásaik lényegi jegyeit, valamint a használatukhoz szükséges speciális készségeket illetôen. Ezt a „tyúk vagy a tojás” problémát tovább bonyolítja az a várható kilátás, miszerint a további technológiai fejlődés növelni fogja a lehetséges termékek és szolgáltatások sokféleségét. A tétlenség, a polgárok tanulási lehetőségeit illető lényegi problémák megoldására való restség ugyanakkor nagyobb kockázatot rejt magában, mint az, ha a piaci fejlődés jelen szakaszában azért mégiscsak megpróbálnánk tenni valamit.

A modern életminőség a digitális technológiákkal és rendszerekkel folytatott interakciók aktív, elkötelezett vállalásától is függ. Az új technológiai rendszer sok mérnök és internetes cég állításaival szemben nem semleges a polgárok társadalmi és kulturális tapasztalatainak és gazdasági kilátásainak vonatkozásában. A szóban forgó rendszerek felépítése, megszerkesztettsége kedvez bizonyos hatások bekövetkeztének. Ezek állandósíthatják a gazdasági növekedés vagy a társadalmi fejlődés bizonyos történelmi mintázatait, de az ezektôl való eltérésnek is kedvezhetnek. A digitális szakadék fennállásának korai jelei azt sugallják, hogy a kirekesztettség az új gazdaságnak is jellemzố vonása lesz. Ez tettre kell, hogy sarkallja a politikát 
annak érdekében, hogy ösztönözzék és előmozdítsák a polgárok részvételét a kialakulóban levố európai tudástársadalmakban. Ugyanilyen politikai lépésekre van szükség annak érdekében, hogy a leglényegesebb politikai irányelvalkotási területeken egy sajátságosan európai „hibridizációs” folyamat kialakulását segítsék elố. A cselekvő politikai fellépés nyomán csökkenhet a gazdasági és társadalmi szereplőket fenyegető bizonytalanság és kockázat, illetve nagyobb fokú összehangoltság jöhet létre az európai tudástársadalmat formáló humán és technológiai állami és magán beruházások vonatkozásában. Az imént vázolt cél elérése érdekében életbevágóan fontos volna a technológiai, társadalmi, kulturális és gazdasági politika egymással összefonódó evolúciója.

Holbok Zoltán forditása

A tanulmány az Aula Kiadónál megjelenés alatt álló, „Bekötőutak az információs kultúrához: az új információs és kommunikációs technológiákhoz való általános hozzáférés problematikája" címû́ kötetben szerepel. Köszönjük az Európa Tanács hozzájárulását a közléshez.

\section{IRODALOM}

ASSENT: "Working Towards Knowledge Society Telematics Applications - Programme Level Report: An Assessment of the Results of the Fourth Framework Telematics Application Programme, Report prepared for the European Commission DGXIII C/E”, The ASSENT (Assessment of Telematics) Project Consortium SU2101, principal responsibility of SPRU University of Sussex, Project SU 2101 Deliverable D09.02. B Rész (6), Brighton, 1999a. június 30.

ASSENT: "Working Towards Knowledge Society Telematics Applications - Telematics and the Disabled and Elderly Sector: An Assessment of the Results of the Fourth Framework Telematics Application Programme, Report prepared for the European Commission DG XIII C/E", The ASSENT Project Consortium SU2101, principal responsibility of Fraunhofer-Institut für Systemtechnik und Innovationsforschung (FhG-ISI), Project 2101 - Deliverable D09.02. Part B (6), Brighton, 1999b. június 30.

Bernal, J. D.(1953): Science and Industry in the Nineteenth Century. London, Routledge and Kegan Paul.

Betcherman, G. \& K. McMullen, (1997): "Impact of Information and Communication Technologies on Work and Employment in Canada", mimeo, Statistics Canada, Ottawa

Buber, M. (1965): Between Man and Man. fordította R. G. Smith, angolul először megjelent 1948-ban, New York, Macmillan.

Buber, M. (1970): I and Thou, fordította W. Kaufman, angolul először megjelent 1937-ben, New York, Charles Scribner.

Castells, M. (1998): The Information Age: Economy, Society and Culture - III. kötet - End of Millennium. Oxford, Blackwell.

Department of Commerce, „Digital Economy 2000”, a beszámolót készítette: Economics and Statistics Administration, Office of Policy Development, Washington, D.C., 2000. június 
Dyson, E. (1997): Release 2.0: A Design for Living in the Digital Age. London, Viking.

Flichy, P. (1995): Dynamics of Modern Communication: The Shaping and Impact of New Communication Technologies. London, Sage Publications.

Geuna, A. \& W. E. Steinmueller (1997): "Joining the Information Society: Internet Access Issues for Europeans", SPRU, University of Sussex, FAIR Working Paper No. 17, Brighton, 1997. február.

Hawkins, R., R. Mansell \& W. E. Steinmueller (1999): „Toward Digital Intermediation in the Information Society", Journal of Economic Issues, Évf. XXXIII, 2. szám, 1999, 38391.0.

High Level Group of Experts, "Building the European Information Society For Us All: Final Policy Report of the High-level Expert Group, DG for Employment, Industrial Relations and Social Affairs", Office for Official Publications of the European Communities, Luxembourg, 1997.

KPMG, "The Impact of the New Economy on Poor People and Developing Countries", végsô beszámoló vázlata a UK Department for International Development számára, London, 2000. július.

Lane, R. E. (1966): "The Decline of Politics and Ideology in a Knowledgeable Society", American Sociological Revierw, 31, 649-62. o.

Leebaert, D. (ed.) (1998): The Future of the Electronic Marketplace. Cambridge, MA, The MIT Press.

Mansell, R. (1999): "New Media Competition and Access: The Scarcity-Abundance Dialectic", New Media \&̊ Society, 1. érf, 2. szám, 1999, 155-182.o.

Mansell, R., I. Schenk \& W. E. Steinmueller (1999): „Net Compatible: The Economic and Social Dynamics of E-commerce", Communications \&̊ Strategies, 38. évf., második negyedév, 1999, 241-76.0.

Mansell, R. \& W. E. Steinmueller (1998): "Intellectual Property Rights: Competing Interests on the Internet", Communications \& Strategies, 30.évf., második negyedév, 1998, 173-97.o.

Mansell, R. \& W. E. Steinmueller (2000): Mobilising the Information Society: Strategies for Growth and Opportunity. Oxford, Oxford University Press.

Mansell, R. \& U. Wehn (eds) (1998): Knowledge Societies: Information Technology for Sustainable Development, published for the United Nations Commission on Science and Technology for Development. Oxford, Oxford University Press.

Marvin, C. (1988): When Old Technologies Were New: Thinking About Electric Communication in the Late Nineteenth Century. Oxford, Oxford University Press.

Mill, J. S. (1868): Dissertations and Discussions: Political, Philosophical and Historica, W. V. Spencer, 1. kötet, Boston.

Neice, D. (2000): "Access to Digital Technologies: Implications for Social Status", nem közölt doktori disszertáció. Brighton, SPRU, University of Sussex.

OECD (1996), "Knowledge-based Economy”, OECD/GD(96)102, Párizs, 1996.

OECD (2000), OECD Information Technology Outlook: ICTs, E-commerce and the Information Economy, OECD, Párizs, 2000.

Ohkawa, K. \& H. Rosovsky (1972): Japanese Economic Growth. Stanford, Kalifornia, Stanford University Press. 
Polanyi, M. (1966): The Tacit Dimension. London, Routledge and Kegan Paul.

Raymond, E. S. (1999): The Cathedral and the Bazaar: Musings on Linux and Open Source by an Accidental Revolutionary. Sebastopol, Kalifornia, O'Reilly \& Associates, Inc.

Richardson, R. (1999): "Call Centres and the Prospects for Export-Oriented Work in the Developing World: Evidence from Western Europe", in S. Mitter and M.-I. Bastos (eds) Europe and Developing Countries in the Globalised Information Economy: Employment and Distance Education. London, Routledge.

Roche, E. M. \& M. J. Blaine (eds) (2000), Information Technology in Multinational Enterprises. Cheltenham, Edward Elgar.

Rogers, E. M. (1983): Diffusion of Innovations, Third Edition. New York, The Free Press.

Turkle, S. (1988): “Computational Reticence: Why Women Fear the Intimate Machine”, in C. Kramerae (ed.) Technology and Women's Voices. London, Routledge.

Turkle, S. (1995): Life on the Screen: Identity in the Age of the Internet. New York, Simon \& Schuster. United Nations Development Programme, Globalisation with a Human Face, UNDP Human Development Report, tizedik kiadás, Getty Center for Education in the Arts, Washington, D.C., 1999. 